\title{
APPRAISAL OF UNCONTROLLED FLOWING ARTESIAN WELLS IN FLORIDA
}

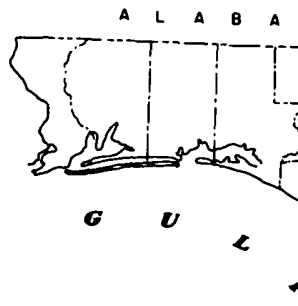

\section{U.S. GEOLOGICAL SURVEY}

Water-Resources Investigations 78-95

Prepared in cooperation with the FLORIDA DEPARTMENT OF ENVIRONMENTAL REGULATION BUREAU OF WATER RESOURCES MANAGEMENT

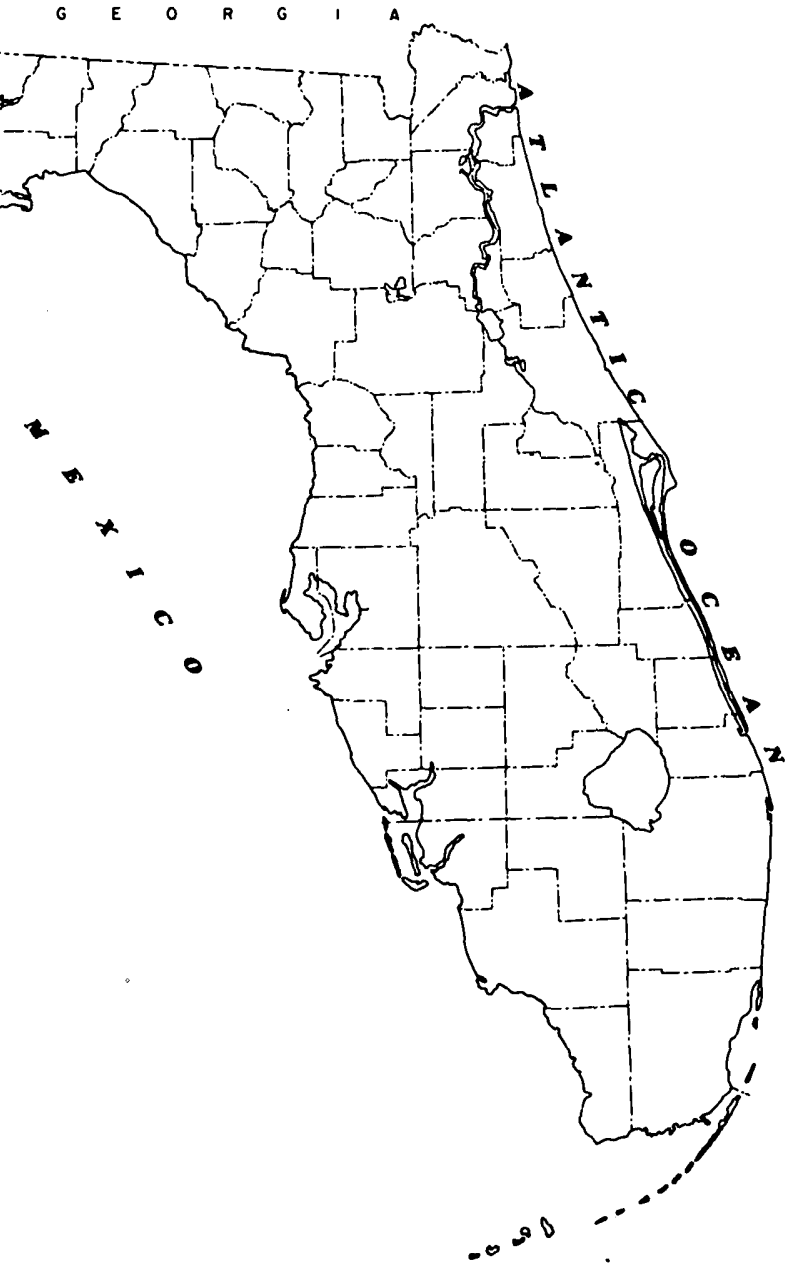




\begin{tabular}{|c|c|c|}
\hline $\begin{array}{l}\text { BIBLIOGRAPHIC DATA } \\
\text { SHEET }\end{array}$ & 1. Report No. & 3. Recipient's Accession No. \\
\hline \multirow{2}{*}{\multicolumn{2}{|c|}{$\begin{array}{l}\text { 4. Title and Subtitle } \\
\text { APPRAISAL OF UNCONTROLLED FLOWING ARTESIAN } \\
\text { WELLS IN FLORIDA }\end{array}$}} & $\begin{array}{l}\text { 5. Report Date } \\
\text { December } 1978\end{array}$ \\
\hline & & 6. \\
\hline \multicolumn{2}{|l|}{$\begin{array}{l}\text { 7. Auchor(s) } \\
\text { Henry G. Healy }\end{array}$} & $\begin{array}{l}\text { 8. Performing Organization Rept. } \\
\text { No.USGS/WRI 78-95 }\end{array}$ \\
\hline \multirow{2}{*}{\multicolumn{2}{|c|}{$\begin{array}{l}\text { 9. Performing Organizatir, Name and Address } \\
\text { U.S. Geologicil Survey, Water Resources Division } \\
\text { Suite F-240 } \\
325 \text { John Tnox Road } \\
\text { Tallahassee, Florida } 32303\end{array}$}} & 10. Project/Task/Work Unit No. \\
\hline & & 11. Contract/Grant No. \\
\hline \multirow{2}{*}{\multicolumn{2}{|c|}{$\begin{array}{l}\text { 12. Sponsoring Organization Name and Address } \\
\text { U.S. Geological Survey, Water Resources Division } \\
\text { Suite F-240 } \\
325 \text { John Knox Road } \\
\text { Tallahassee, Florida } 32303\end{array}$}} & $\begin{array}{l}\text { 13. Type of Report \& Period } \\
\text { Covered }\end{array}$ \\
\hline & & 14. \\
\hline
\end{tabular}

15. Supplementary Notes

16. Abstracts

An estimated 15,000 uncontrolled flowing we11s statewide are wastefully discharging about 790 million gallons per day by surface and internal flow. Seventy percent of the discharge, 550 million gallons per day, is from uncontrolled flowing wells in 14 counties in east-coastal and southwest parts of the State. Programs for the control of flowing wells are being carried on by state, county, municipal, or federal agencies in 21 counties.

17. Key Words and Document Analysis. 17a. Descriptors

Aquifers, artesian wells, subsurface flow, saltwater intrusion

17b. Identifiers/Open-Ended Terms

Florida, Floridan aquifer, unconfined aquifers

17c. $\cos \Lambda$ TI Field/Group

18. Availability Statement

No restriction on distribuiton.

19. Security Class (This Report)

UNCIUASSIEIED

20. Security Class (This

Page

UNCLASSIFIED

THIS FORM MAY BE REPRODUCED
21. No. of Pages

26 
APPRAISAL OF UNCONTROLLED FLOWING

ARTESIAN WELLS IN FLORIDA

By Henry G. Healy

U.S. GEOLOGICAL SURVEY

Water-Resources Investigations 78-95

Prepared in cooperation with the

FLORIDA DEPARTMENT OF ENVIRONMENTAL REGULATION BUREAU OF WATER RESOURCES MANAGEMENT

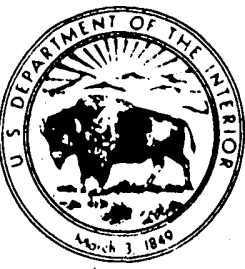

1978 
UNITED STATES DEPARTMENT OF THE INTERIOR

CECIL D. ANDRUS, Secretary

GEOLOGICAL SURVEY

H. William Menard, Director

For additional information write to:

U.S. Geological Survey

325 John Knox Road

Suite F-240

Tallahassee, Florida 32303 
Abstract ........................ . . 1

The flowing well problem . . . . . . . . . . . . . 2

Historical summary. . . . . . . . . . . . . . 2

Purpose and scope. . . . . . . . . . . . . . . . . 6

Factors influencing flow. . . . . . . . . . . . 7

Effects of uncontrolled flow. . . . . . . . . . . . 7

Areas of uncontrolled flowing wells.............. . 13

Density and distribution of wells . . . . . . . . . 13

Estimated number of wells . . . . . . . . . . 13

Quantity of water discharged. ............. 16

Surface flow.................. 16

Internal flow. . . . . . . . . . . . . 17

Principal problem areas . . . . . . . . . . . . 17

Methods of controlling flowing wells . . . . . . . . . . 18

Program for controlling flowing wells. . . . . . . . . . . 21

Summary. . . . . . . . . . . . . . . . . . . . 24

References ........................ . 25

\section{ILLUSTRATIONS}

Figure 1. Map showing areas of water supply from shallow aquifers and the thickness of the zone of potable water in the Floridan aquifer.......... 3

2. Map showing numbers of uncontrolled flowing artesian wells.................. 5

3. Schematic diagrams showing: A) Relation between saltwater and freshwater illustrating the Ghyben-Herzberg principle, and B) its effect in an artesian aquifer where potentiometric surface has declined... . 9

4. Schematic diagram illustrating migration of poor quality water by upward leakage through corroded casings or improperly constructed wells . . . . 10

5. Schematic diagram illustrating variations of internal flow induced by pumping . . . . . . . . . 12

6. Map showing areas of artesian flow from the Floridan aquifer, May 1974 .............. 14

7. Map showing principal problem areas of uncontrolled flowing artesian wells. . . . . . . . 15

\section{TABLES}

Table 1. Summary of pertinent data on uncontrolled artesian flow in principal problem areas in Florida by counties...................... 19

2. Summary of current programs for the control of flowing wells in Florida by counties. . . . . . . . 22 
For use of those readers who may prefer to use metric units rather than U.S. customary units; the conversion factors for the terms used in this report are listed below:

Multiply U.S. customary unit

inch (in.)

foot $(\mathrm{ft})$

gallons per minute (gal/min)

square mile $\left(\mathrm{mi}^{2}\right)$

million gallons per day

(Mgal/d)
By

25.4

.3048

.06309

2.590

.04381
To obtain metric unit

millimeter (mm)
meter $(\mathrm{m})$
liters per second $(\mathrm{L} / \mathrm{s})$
square kilometer $\left(\mathrm{km}^{2}\right)$
cubic meters per second
$\quad\left(\mathrm{m}^{3} / \mathrm{s}\right)$


APPRAISAL OF UNCONTROLLED FLOWING

ARTESIAN WELLS IN FLORIDA

By Henry G. Healy

\begin{abstract}
An estimated 15,000 uncontrolled flowing wells, many discharging water of poor quality are wastefully discharging about 790 million gallons per day by surface and internal flow. Internal flow in principal problem areas in 14 counties is estimated at 550 million gallons per day. Fourteen principal problem areas have been identified in Brevard, Charlotte, Clay, De Soto, Duval, Flagler, Glades, Hendry, Hillsborough, Lee, Manatee, Martin, Nassau, and Sarasota Counties.

In many areas, uncontrolled discharge over the years has caused a decline in the potentiometric surface locally and regionally, and a deterioration of the potable water aquifers. Programs for control of flowing wells are being carried on by state, county, municipal, or federal agencies in 21 counties.
\end{abstract}




\section{THE FLOWING WELL PROBLEM}

In 1956 the Florida Water Resources Study Commission identified "wasteful flow" from uncontrolled flowing artesian we1ls in 29 counties as being one of three most important water problems in Florida. The other two are saltwater encroachment (20 counties) and reduction of flow from wells (28 counties) (Hendry and Lavender, 1959, p. 12).

Uncontrolled flowing artesian wells, improperly constructed and maintained, contribute to waste by surface flow and, in many areas, are the principal means of deterioration of freshwater by upward leakage of saltwater into water-table aquifers, shallow artesian aquifers, and upper zones of the Floridan aquifer used as sources of water supply.

Hendry and Lavender (1957, p. 19) define wildly flowing wells as, "...those that have been abandoned and flowing, those used mainly for irrigation and livestock which are permitted to flow continuously, and those wells provided with valves which are now inoperative to some degree, permitting leakage." In this report, an uncontrolled or freeflowing well is an artesian well either without a mechanism for controlling discharge or a well that is allowed to flow continuously at the land surface as well as those wells that only flow internally below land surface through corroded or leaky casings or from improperly cased or otherwise poorly constructed wells.

Shallow aquifers are becoming increasingly important as sources of ground-water supply, particularly in those areas where water in the Floridan aquifer system is highly mineralized or where freshwater zones in the Floridan are relatively thin (fig. 1). In southwest Florida-in Collier, Charlotte, Lee, and Sarasota Counties--pumpage from shallow aquifers for municipal and industrial uses increased from $26 \mathrm{Mgal} / \mathrm{d}$ in 1970 (Pride, 1973) to about $35 \mathrm{Mgal} / \mathrm{d}$ in 1975 (Leach, 1978). In east and southeast coastal Florida--in Brevard, Flagler, Indian River, Martin, Palm Beach, St. Johns, and St. Lucie Counties--shallow aquifer pumpage increased from $24 \mathrm{Mgal} / \mathrm{d}$ in 1970 (Healy, 1972) to about 73 Mgal/d in 1975 (Healy, 1977). The increased use of ground water has resulted in considerable stress to the shallow aquifers; consequently, water levels have declined and some deterioration in the quality of freshwater has occurred.

\section{Historical Summary}

A summary of the chronological history (1903-1955) of waterconservation laws and acts that relate to ground water is presented by Hendry and Lavender (1957, pp. 12-16). According to Hendry and Lavender (1957, p. 14) the first legislative action specifically for regulation and control of flow in wells in Sarasota, Manatee, and Seminole Counties was enacted in 1953. A statewide inventory of flowing artesian we1ls was promoted by the Florida Association of Soil Conservation District Supervisors and the Florida Water Resources Study Commission in 1954-56 


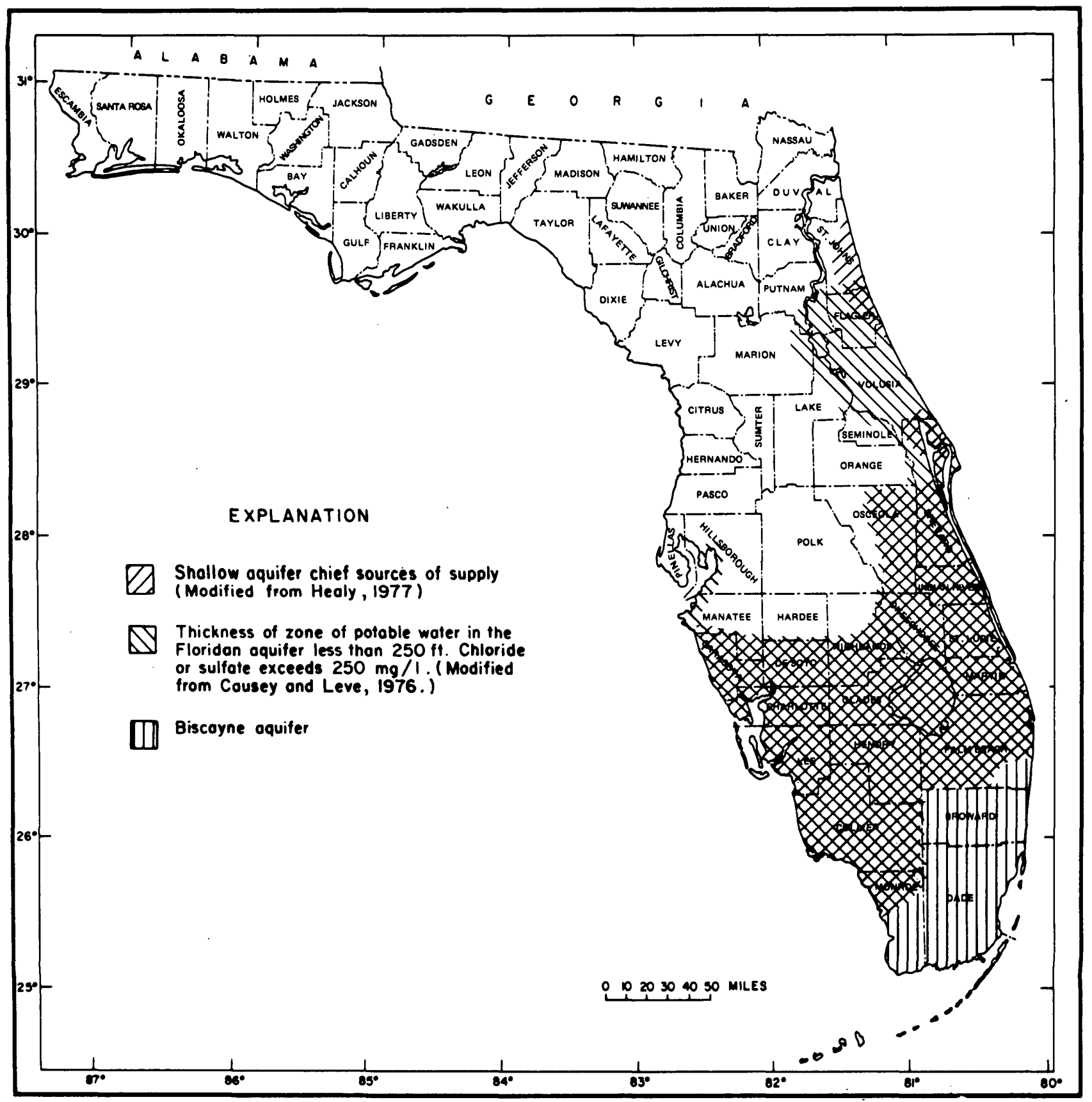

Figure 1.--Areas of water supply from shallow aquifers and the thickness of the zone of potable water in the Floridan aquifer. 
(Hendry and Lavender, 1959, p. 12). In response to a request by the state legislature, the then Florida Geological Survey located 1,883 wild flowing wells in 44 counties during 1956-57 (Hendry and Lavender, 1959). Several recent inventories of uncontrolled flowing artesian wells have been made by the U.S. Geological Survey in local areas in cooperation with water management districts and county and local programs for investigating and reducing the number of uncontrolled flowing wells. The numbers of uncontrolled flowing wells inventoried by the Florida Geological Survey in 1956 and 1957 plus the estimated or inventoried numbers of wells flowing internally and on the surface made by the U.S. Geological Survey in 1977, are shown on figure 2.

In many areas, uncontrolled flowing artesian wells were recognized and reported as a potential problem by early investigators of water resources in Florida. The reports briefly discuss: (1) effects of uncontrolled flowing wells in Manatee County (Peek, 1958; and Peek and Anders, 1955); Hillsborough County (Peek, 1953); and (2) deterioration of shallow aquifers by upward leakage and internal flow in Glades and Hendry Counties (Klein and others, 1964), in Martin County (Lichtler, 1960), and in Lee County (Boggess and others, 1977).

During the period 1900 to early 1950's, thousands of wells were drilled into the Floridan aquifer to obtain artesian (flowing) water for irrigation and stock watering. Most of the wells were in coastal and inland agricultural areas of low elevation where artesian flow from the Floridan aquifer offered an easily procurable, relatively inexpensive, and reliable source of water supply. The water, however, was saline in some areas. Cooper and Stringfield (1950, p. 6), in discussing some problems of development and conservation, state "...apparently the fact that the artesian water is salty in some areas has not greatly limited its use for irrigation. Hundreds of flowing wells that yield water too salty for municipal and most industrial uses are being used for irrigation along the east and west coasts. Many yield water having a chloride content of more than 1,000 parts per million."

Well drilling practices in many areas include casing a well only part of its entire depth. For example, a well drilled 600 to 800 feet deep might contain only $80 \mathrm{ft}$ of casing (Klein and others, 1964). The length of casing depends upon economic factors as well as hydrologic and geologic conditions at the well site. An uncased hole penetrating two or more aquifers allows free circulation between the aquifers. Water in the deeper aquifers generally is under higher pressure and more mineralized than water in the more shallow aquifers. Thus deep and improperly cased wells allowed upward migration and mixing of the mineralized water with water in the more shallow aquifers, and consequently, contamination and deterioration in the quality of water in the shallower aquifers. In southwest Florida, particularly, in Manatee, Sarasota, Charlotte, and Lee Counties, the use of black-iron casings was widespread. In time, however, the casings deteriorated because of the corrosive effect of high chloride and sulfate concentration of the ground water and began leaking saltwater into shallow aquifers, which reduced the usefulness of 


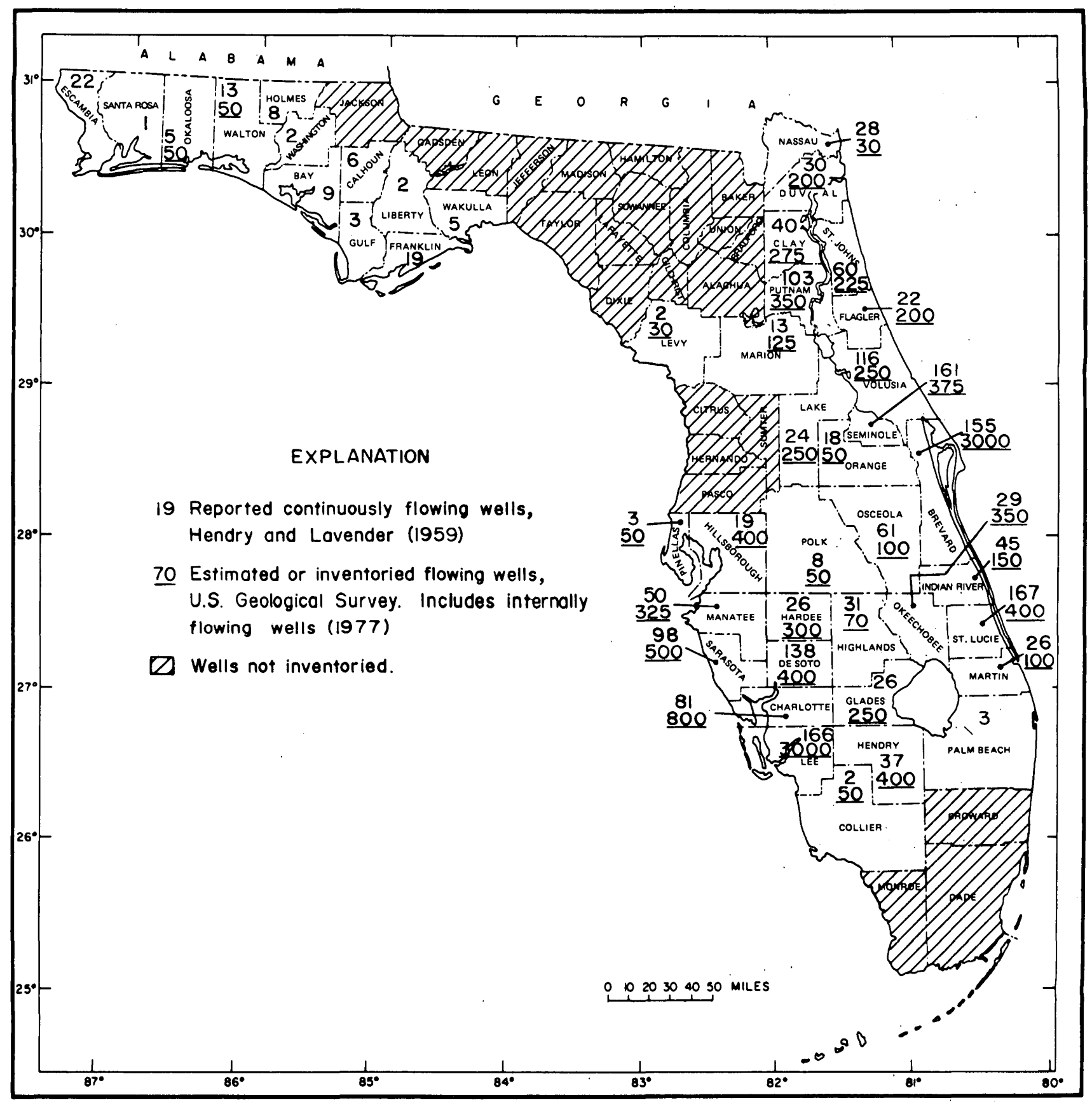

Figure 2.--Numbers of uncontrolled flowing artesian wells. 
those aquifers as potential sources of water supply. In addition, contamination of underlying aquifers has occurred by downward leakage of saltwater through corroded casings of wells drilled in areas adjacent to tida1. water bodies in Lee County (Boggess and others, 1977) and in Okaloosa County (Trapp and others, 1977).

In recent years, many areas formerly used for agriculture are being converted to residential to accommodate the burgeoning population.

Wells in former agricultural areas were abandoned and no effort was made to halt the uncontrolled flow from these wells. With development of homesites and trailer parks, many of the abandoned wells were either plugged at the surface or covered by construction. Also many wells that formerly flowed at the surface ceased flowing when artesian pressures declined because of increased local or regional pumping, or drought. Many of those wells are hardly recognizable as wells today because of the deterioration of the casing at the surface. The surface expressions of many appear as seeps and springs rather than continuously discharging wells.

An increased awareness of developing water problems during the successive wet and dry periods of 1948-49 and 1950-52 resulted in enactment of regulatory measures by the 1953 State Legislature (Chapter 370.051-370.055, Florida Statutes, 1953). These statutes required that valves be installed on all flowing wells and that uncontrolled flowing artesian wells be capped or plugged.

Failure to enforce the provisions of many of the early laws resulted from: (1) The lack of knowledge or comprehension of the seriousness of the problem; (2) the fact that each law had a restricted areal application rather than being statewide in scope and application; and (3) the "imbedding" of a potentially effective good law with a host of other special laws which were neither approved nor appropriately funded (Hendry and Lavender, 1957, p. 13).

\section{PURPOSE AND SCOPE}

Extensive and expanded use of ground water for municipal, industrial, and agricultural supplies has resulted in the need for a thorough and continuing assessment of ground-water resources in the State. The problem of artesian wells flowing uncontrolled at and below land surface is of importance to the conservation of the State's water supply. An evaluation of problem areas will provide state regulatory agencies with a sound basis for making management decisions necessary for the protection of shallow aquifers and to effectively reduce and otherwise control water loss from uncontrolled flowing wells.

This report appraises the problem of flowing wells in Florida. It presents a general statewide summary of uncontrolled flowing artesian wells based on data available from reports and field data files. The report emphasizes principal problem areas and includes the estimated 
number of uncontrolled flowing wells and their impact, primarily on contamination of shallow aquifers. This report is the result of cooperative study with the Florida Department of Environmental Regulation to obtain information on the importance and magnitude of the problem of uncontrolled flowing wells and any existing programs of control.

\section{Factors Influencing Flow}

Control of flowing wells involves an understanding of the physical factors influencing flow. The yield of a well by artesian flow is controlled by many variables which may be divided into the general categories of well construction and the geologic and hydrologic characteristics of the aquifer.

The length of casing in relation to the total depth of the well is important in controlling the quantity of water flowing at the well head or internally. Sproul and others (1972, p. 10) reported that the internal leakage within uncased parts of wells ranged from about 30 to nearly $100 \mathrm{gal} / \mathrm{min}$ (gallons per minute) in the McGregor Isles area, Lee County. The relation of this and other factors to flow have been treated at length in reports of hydrologic and water-resources investigations. Factors influencing well yields have been discussed in detail by many authors, including Boggess (1974), Wilson (1977), and Lichtler (1960).

\section{Effects of Uncontrolled Flow}

Uncontrolled artesian flow affects ground-water resources by: lowering the potentiometric surfaces; decreasing volumes of flow; and causing migration of saltwater into freshwater zones under certain geologic and hydrologic conditions.

The potentiometric surface of the Floridan aquifer fluctuates continuously in response to changes in the quantities of water recharged to and discharged from the aquifer. The potentiometric surface rises during wet periods and declines during dry periods. Hydrostatic or hydrodynamic pressure of the water in the aquifer, represented by the potentiometric surface or water level in the well, normally acts as a pressure barrier to prevent highly mineralized water from migrating into the freshwater aquifer. Thus, declines in water levels may signal the eventual migration of saltwater into the freshwater part of the Floridan aquifer, particularly in coastal areas, except where such migration is prevented by impermeable beds.

Generally, under hydrostatic equilibrium, the depth of freshwater below mean sea level is about 40 times the height of the potentiometric surface above mean sea level, or, for each foot that the potentiometric surface stands above mean sea level, the freshwater will extend an additional $40 \mathrm{ft}$ below sea level. Generally, a decline of one foot of freshwater will result in an approximate rise of $40 \mathrm{ft}$ of saltwater. 
This relation between saltwater and freshwater, is the Ghyben-Herzberg principle and provides the mechanism by which saltwater encroachment takes place. The principle and its application has been described and discussed in many reports of ground-water resource studies, including Heath and Smith (1958), Lichtler (1960), McCoy (1962), and Peek (1959). The principle has been modified to apply to the dynamic condition of constant ground-water flow. The modifications, however, are usually minor and the Ghyben-Herzberg ratio can be used to estimate the minimum depth to saltwater in areas adjacent to and underlain by seawater (Heath and Smith, 1958, and Lichtler, 1960).

Figure 3-A is a generalized cross section of Florida-illustrating the relation between freshwater and saltwater. Figure 3-B shows the upward migration of saltwater of about $40 \mathrm{ft}$ (from 400 to $360 \mathrm{ft}$ ) in response to 1-foot decline of the potentiometric surface in the artesian aquifer. In figure $3-B$ the saltwater has migrated into the upper part of the aquifer that previously contained only freshwater.

Some of the ways contamination by saltwater from wells occurs through corroded casings, improperly constructed wells, and by pumping conditions are illustrated by figures 4 and 5 .

In many counties in southwest and east-coastal Florida, shallow aquifers are the only sources of freshwater. In several locations these aquifers are being contaminated by upward migration of highly mineralized water from the underlying Floridan aquifer. Upward movement of saltwater can occur in several ways as schematically illustrated in figure 4 and.figure 5. The horizontal distance between wells in figures 4 and 5 is not significant. Each well represents an isolated example showing different types of internal flow. The following descriptions apply to figure 4 .

We11 A.--Properly constructed flowing artesian well with valve that taps the secondary artesian aquifer. No contamination occurring, but could receive contamination if nearby wells such as well B exist.

We11 B.--Abandoned flowing artesian well with corroded casing in the secondary artesian aquifer and open well bore to saltwater in the top of the artesian aquifer. Saltwater is flowing up the open we11 bore and through corroded casings and contaminating three freshwater aquifers: the secondary artesian aquifer; the shallow artesian aquifer; and the water-table aquifer. Surface flow is also contaminating the water-table aquifer.

Well C.--Abandoned flowing artesian well with an uncased well bore. Saltwater from the deeper part of the artesian aquifer is flowing up the open well bore and contaminating the three overlying freshwater aquifers. Surface flow from this well is also contaminating the water-table aquifer and adjacent surface-water bodies. 
(A)

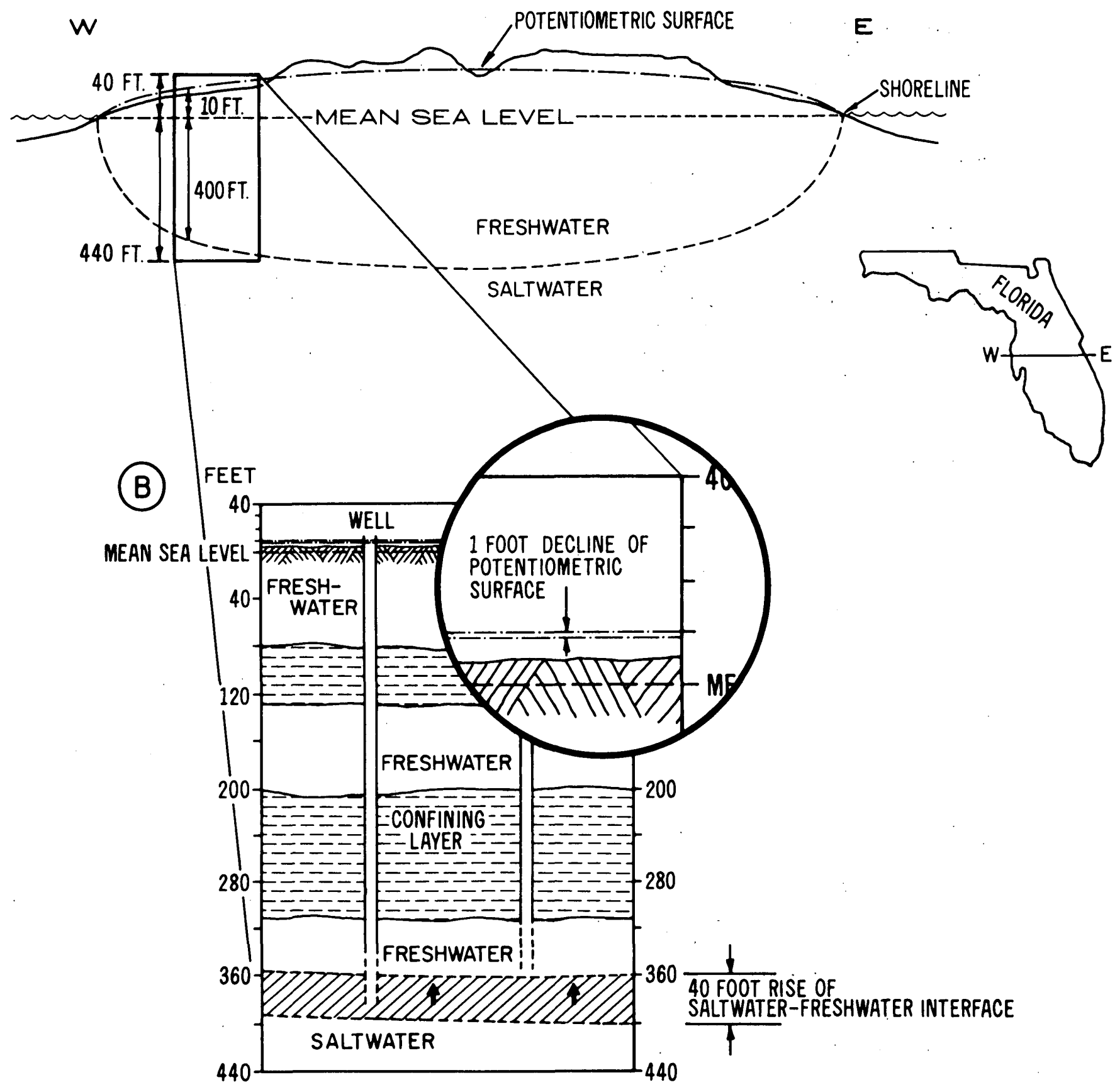

Figure 3.--Schematic diagrams showing (A) Relation between saltwater and freshwater illustrating the Ghyben-Herzberg principle, and (B) and its effect in an artesian aquifer where potentiometric surface has declined. 


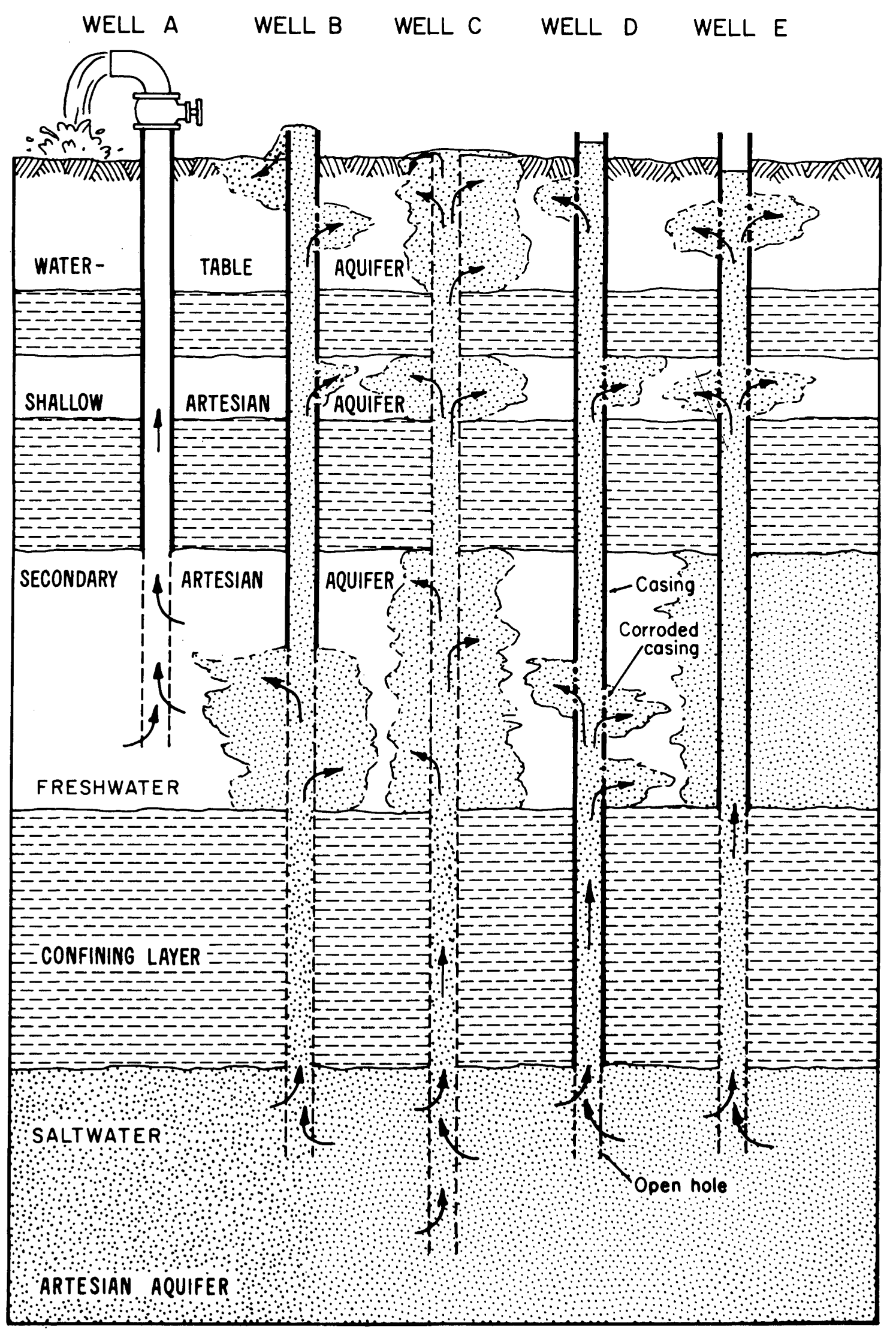

Figure 4.--Schematic diagram illustrating migration of poor quality water by upward leakage through corroded casings or improperly constructed wells. 
We11 D.--Properly constructed artesian well cased through the upper aquifers and confining layers with open hole only into the saltwater in the upper part of the artesian aquifer. Saltwater flowing upward contaminates both shallow artesian and water-table aquifers through corroded casing. This well is not flowing at the surface but has the potential to flow if the potentiometric surface (water level) rises.

We11 E.--Abandoned artesian we11 cased through saltwater of secondary artesian aquifer and confining layer with open hole into the upper section of the Floridan aquifer. Although this well does not flow at the surface, internal or interaquifer flow is taking place. Saltwater is flowing up the well bore and contaminating, by internal leakage through corroded casing, freshwater in the shallow artesian and watertable aquifers.

Some possible combined effects of pumping and internal flow on aquifer contamination are schematically illustrated in figure 5.

We11 I.--Saltwater migrating toward the pumping well from a nearby non-pumping well. The source of saltwater is an abandoned deep well with leaky casing (well I').

We11 I'.--This well is contaminating the secondary artesian aquifer by upward flow outside the casing and the water-table aquifer by flow through leaking casing.

We11 II.--Migration of saltwater from leaky abandoned deep well (well I') towards the shallow well.

Well III.--Pumping well tapping the secondary artesian aquifer and the artesian aquifer. Water from this well is being contaminated by downward and lateral migration of saltwater from abandoned well III'.

We11 III'.--Abandoned well with corroded casing. The leaky upper casing allows saltwater from the water-table and shallow artesian aquifers to contaminate the underlying freshwater in the secondary artesian aquifer by downward leakage. The source of the saltwater in the shallow aquifers is from adjacent tidal saltwater bodies. (Hydraulic condition shown in well III' is not related to well IV.)

Well IV.--Abandoned supply well showing migration of contaminated water entering the well from the lower saltwater zone of the secondary artesian aquifer and entering the shallow artesian aquifer through leaky casing. Contamination of the water-table aquifer is also occurring through leaky casing.

We11 V.--Pumping well tapping the secondary artesian aquifer. Source of the contamination is. saltwater leaking from well IV into the shallow artesian aquifer. The water enters well $\mathrm{V}$ through corroded and leaky casing. 
WELL I WELLI' WELL II WELL III

WELL II' WELLI WELL $\mathbb{Z}$

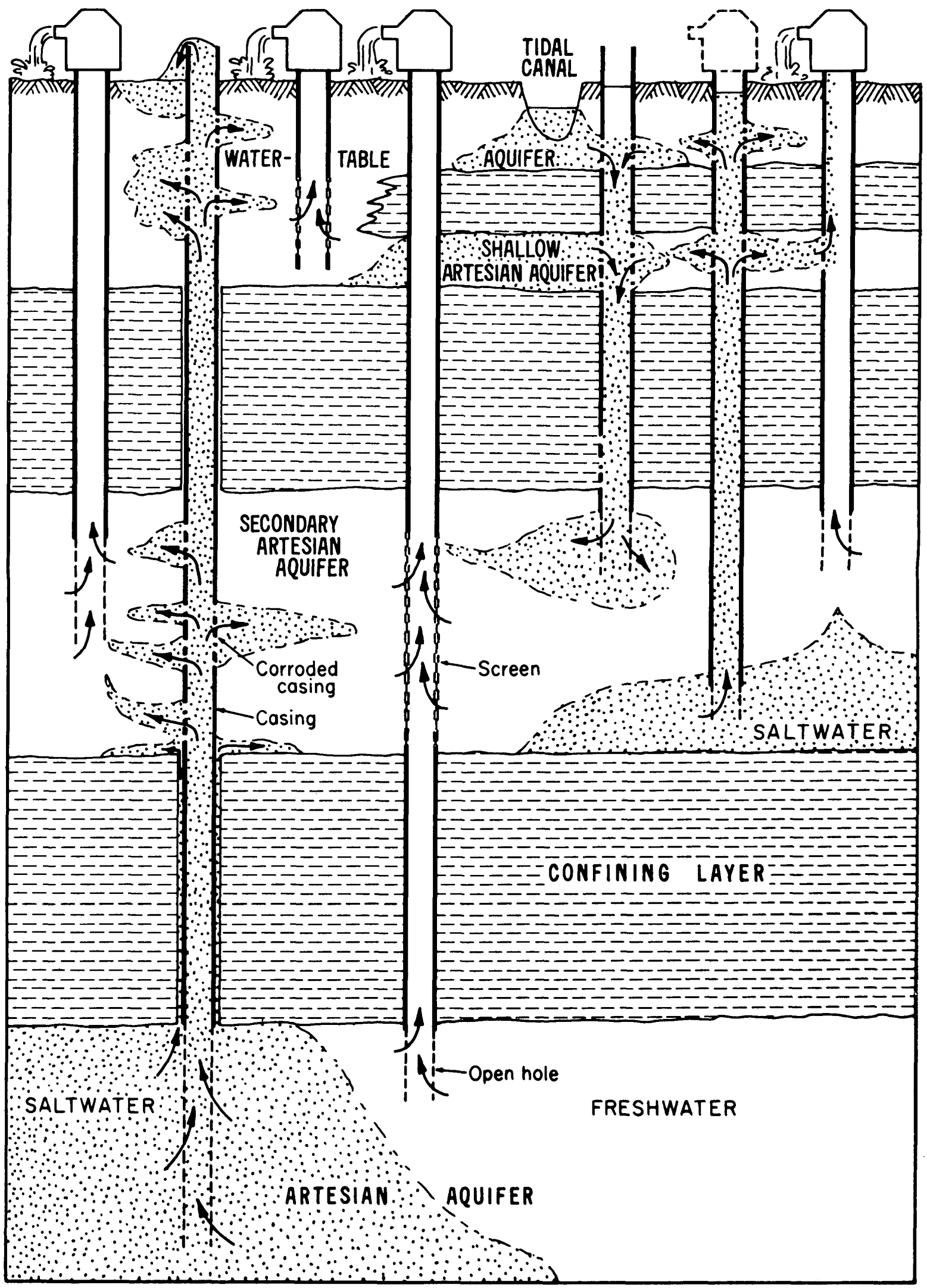

Figure 5.--Schematic diagram illustrating variations of internal flow induced by pumping. 
Although surface flow often can be measured readily, internal flow is more difficult because variations in construction, aquifer characteristics, and corroded casings. Nevertheless, some measurements of internal flow from one aquifer to another have been made in wells by current meters and geophysical equipment and on an areal basis by water quality criteria. Water loss to overlying aquifers by leakage is discussed under Quantity of Water Discharged.

\section{AREAS OF UNCONTROLLED FLOWING WELLS}

\section{Density and Distribution of Wells}

Water will flow at the surface from wells tapping the Floridan aquifer in $19,700 \mathrm{mi}^{2}$, or 36 percent of the state (Healy, 1975). Principal areas of surface flow include the Atlantic east coast and the southern third of the peninsula (fig. 6).

Uncontrolled flowing artesian wells were reported in 44 counties in 1956-57 (Hendry and Lavender, 1959, p. 29, table 2). The statewide distribution of wells flowing at the surface and internally, by: counties (fig. 2) shows that a large percentage of the wells is in two areas--in east coastal Florida, extending from Nassau to Martin Counties, and in the southwest along the Gulf coast extending from Hillsborough to Lee Counties. At least 250 or more uncontrolled flowing artesian wells are in each of 10 of the 14 counties comprising the two areas. The areal distribution and density of flowing wells generally coincide with the extent and location of shallow aquifers used for water supply (figs. 1 and 2).

The geographic distribution of the areas where internal flow occurs is critical. In south Florida, surface and internal flow results in deterioration of the quality of water in the shallow aquifers. Presently these aquifers are the only sources of fresh ground water in coastal areas where extensive development is now occurring and expected in the next 10 to 15 years.

\section{Estimated Number of We1ls}

About 15,000 uncontrolled flowing artesian wells--1,883 inventoried by Hendry and Lavender (1959) and 13,155 estimated by U.S. Geological Survey--are flowing at the surface and internally (fig. 2). About 75 percent of the estimated number of flowing wells are in areas considered to be principal problem areas deficient in freshwater resources (fig. 7). 


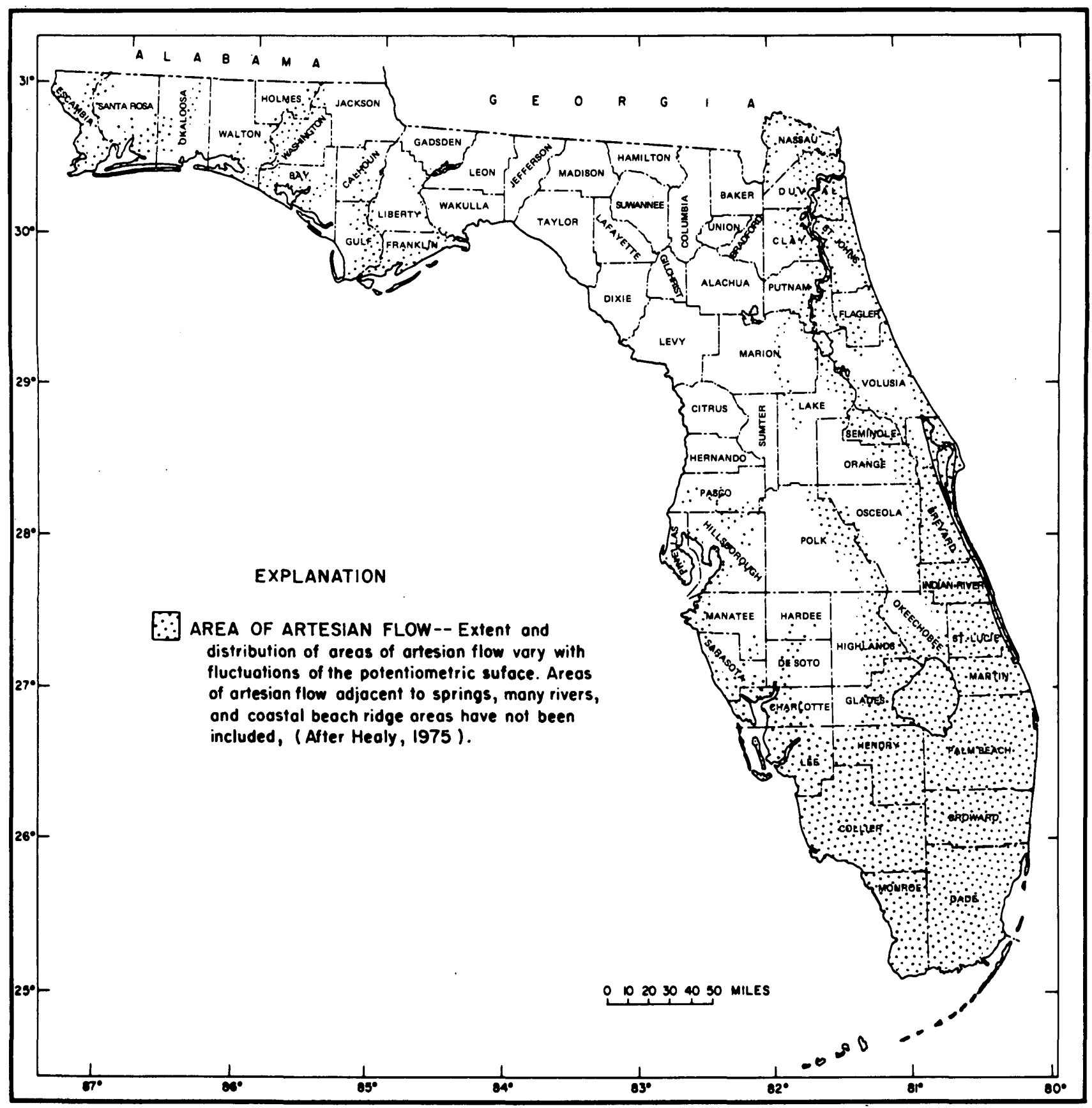

Figure 6.--Areas of artesian flow from the Floridan aquifer, May 1974. 


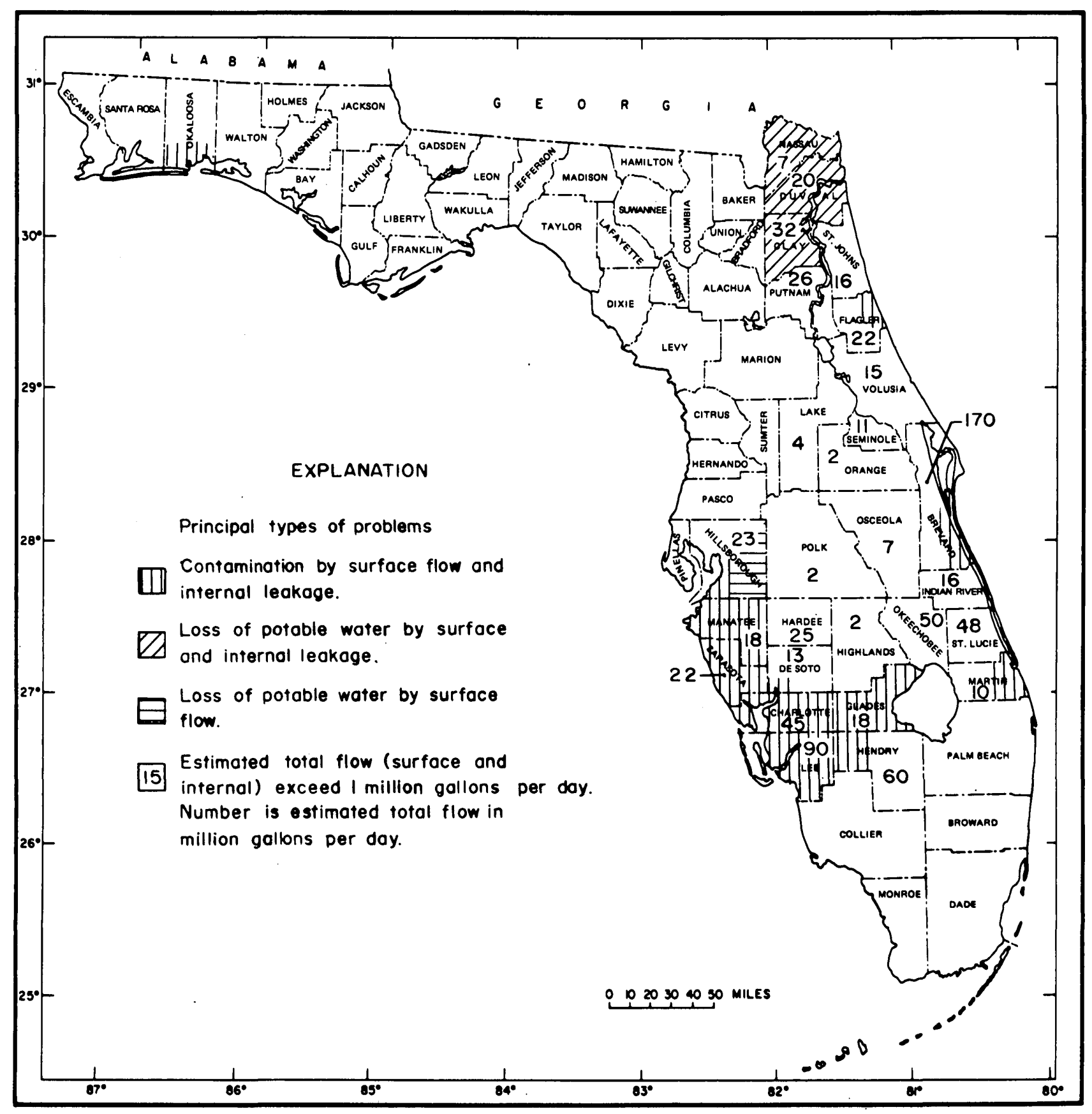

Figure 7.--Principal problem areas of uncontrolled flowing artesian wells. 


\section{Quantity of Water Discharged}

\section{Surface Flow}

Two types of flow from wells tapping artesian aquifers are discussed--surface flow and internal flow. According to Hendry and Lavender (1959, p. 29, table 2), surface flow from 1,883 continuously flowing wells measured nearly $80,000 \mathrm{gal} / \mathrm{min}$ (115 Mgal/d) or about $42 \mathrm{gal} / \mathrm{min}$ per well. The quantity of water flowing at any given time depends on the altitude of the potentiometric surface. Hendry's statewide surface flow figure probably represents higher than average flow per well because of the subsequent decline of the potentiometric surface in many areas during 1959-77.

Presently (1978), the U.S. Geological Survey estimates there are 15,000 uncontrolled flowing artesian wells discharging a total of 790 Mgal/d internally and onto the surface in Florida. Surface flow, statewide, which includes both potable and brackish waters, accounts for approximately $180 \mathrm{Mgal} / \mathrm{d}$ of the total. In contrast to the total statewide water pumped for use (3,318 Mgal/d, Leach, 1978), and by spring discharge (5,000 $\mathrm{Mgal} / \mathrm{d}$, Rosenau and Faulkner, 1974), water flowing to waste from uncontrolled flowing wells is more than 9 percent. However, when compared with the total withdrawn by pumpage only, that amount lost by uncontrolled flowing wells becomes far more significant, approximately 24 percent.

The estimated surface flow from uncontrolled flowing wells is 90 $\mathrm{Mgal} / \mathrm{d}$ in the 14 counties which include significant problem areas. In at least 13 more counties, the artesian flow at the surface from uncontrolled wells exceeds $1 \mathrm{Mgal} / \mathrm{d}$. For the rest of the State, total surface flow is estimated at $15 \mathrm{Mgal} / \mathrm{d}$. High rates of artesian flow are concentrated along the east coast and in areas along and adjacent to the southwest Gulf coast (fig. 7).

In several counties the primary problem is the loss of potable water to the surface rather than contamination of overlying aquifers by internal flow. In Duval County, the freshwater loss from uncontrolled artesian wells in the Jacksonville area, was estimated to be as much as $20 \mathrm{Mgal} / \mathrm{d}$, with an uncontrolled average flow rate of $10 \mathrm{gal} / \mathrm{min}$ from 2inch diameter wells and as much as $300 \mathrm{gal} / \mathrm{min}$ from 4- to 6-inch diameter wells (Leve and Goolsby, 1969, p. 29-30).

In Lee County, the flow from 103 inventioned artesian wells is primarily brackish and averages about $233 \mathrm{gal} / \mathrm{min}(0.33 \mathrm{Mgal} / \mathrm{d})$ with rates ranging from 20 to $750 \mathrm{gal} / \mathrm{min}$ (Boggess, 1974, p. 52). 
Many wells that flow at the surface also flow internally through leaky casings. In Lee County, there are about 3,000 we11s and test holes most of which leak internally (Boggess, oral commun., 1977).

Sproul and others (1972, p. 10) state that in Lee County, "Only small quantities of water are withdrawn from the lower Hawthorn aquifer at the present time (1970). However, water is discharged from this aquifer by upward leakage from the uncased portion of wells. The amount of leakage in individual wells, as measured by geophysical logging methods, ranged from about $30 \mathrm{gpm}$ to nearly $100 \mathrm{gpm}$. Flows less than 30 gpm could not be measured reliably with the instruments used, but it may be assumed that such flow does occur in most wells penetrating the aquifer. Assuming an average leakage rate of only $30 \mathrm{gpm}$ per well, and that at McGregor Isles 40 wells are open to both the upper and lower Hawthorn aquifers, about $1.7 \mathrm{mgd}$ (million gallons per day) is discharged from the lower aquifer as vertical leakage. The quantity of water discharged from the lower aquifer either through wells or along faults probably will increase as the head in the shallower aquifers is lowered by pumping."

In Clay County, Foster (1962, p. 7), in discussing loss of water from leaky wells states, "The estimated water loss in poorly designed wells ranges from 32 to $180 \mathrm{gpm}$. Of the 69 wells inventoried, 14 were found to be leaking, and the total estimated loss of water from the leaky wells amounts to about $1,000 \mathrm{gpm}$. It is assumed that 5 percent of the existing wells were inventoried and it seems probable that the same percentage of leaky wells would be found among all the we1ls in the area. If these assumptions are reasonably correct, the total water loss would be about 20,000 gpm, or about $30 \mathrm{mgd}$." According to Foster, about 20 percent of the wells inventoried were leaking internally an average of $70 \mathrm{gal} / \mathrm{min}$. Internal leakage is not necessarily a "loss" of freshwater from the ground-water system, but movement of water from one aquifer to another as in Clay County. Loss of water would take place if internal leakage allowed mineralized water to flow through leaky casings into freshwater aquifers causing a deterioration in the water quality of the aquifer. Estimated internal flow is $460 \mathrm{Mgal} / \mathrm{d}$ in the 14 counties which include problem areas and $150 \mathrm{Mgal} / \mathrm{d}$ for the remaining 13 counties in central, eastern, and southern areas (fig. 7).

\section{Principa1 Problem Areas}

For the purpose of this report, principal problem areas are those areas where: (1) Surface flow is at least $1 \mathrm{Mgal} / \mathrm{d}$, (2) upward leakage of mineralized water from deep aquifers into overlying freshwater aquifers through leaky well casings or open bore holes has occurred or is occurring, (3) water levels have declined in shallow and in the deeper aquifers, and (4) numerous wells either flow at the surface or flow internally. 
The most current priority problem areas of uncontrolled flowing wells are in parts of Brevard, Charlotte, Clay, De Soto, Duval, Flagler, Glades, Hendry, Hillsborough, Lee, Manatee, Martin, Nassau, and Sarasota Counties. In these 14 counties, total estimated discharge from uncontrolled flowing wells is $550 \mathrm{Mgal} / \mathrm{d}$ of which $460 \mathrm{Mgal} / \mathrm{d}$ is internal and $90 \mathrm{Mgal} / \mathrm{d}$ is at the surface. Principal problem areas are shown in figure 7 and are tabulated by counties in table 1 .

\section{METHODS OF CONTROLLING FLOWING WELLS}

Several methods may be used to control the surface and internal flow of wells. In determining which method to use, the well bore must first be examined with several geophysical logging devices to determine the length and condition of the casing and those horizons where water may be entering the well. If the casing is intact and of proper length, and effectively sealing off strata that contain undesirable water, the well may simply be capped or valved. Capping and valving methods of flow control do not offer a satisfactory solution when the casing is corroded or otherwise defective. If the casing is corroded or of insufficient length, or if this information is unattainable, then the bore hole must be plugged. One method is to place inside the well bore a plug or series of plugs above (upward leakage) or below (downward leakage) the horizon or horizons from which flow into the bore is identified from geophysical logs. The plug can consist of a fasthardening cement or some other material and may extend throughout the entire depth of the well and include open bore as well as cased hole, or a series of plugs may be used to seal off different aquifers from which undesirable water may enter the well bore. If a well is capped without examining and evaluating the condition of the casing, the capped well may continue to flow internally and contaminate freshwater aquifers with mineralized water. In discussing control procedures for eliminating the intrusion of saline water from deep aquifers, Sproul and others (1972, p. 27) state, "...capping a well at the surface in no way diminishes the effects of intruding water into the upper Hawthorn or sandstone aquifers, and may actually exacerbate the problem."

Cap and valve control are the lowest cost means of controlling surface flow but will not control internal flow. Well plugging offers the most effective but most expensive method of controlling both surface and internal flow. In 1977, costs for plugging with cement varied from a few hundred to thousands of dollars per well depending upon the length of the well bore to be sealed. According to the Sarasota County Health Department ( $R$. Walcott, oral commun., 1977), plugging 5 wells throughout their entire length cost $\$ 6,000$. Costs vary from area to area depending upon the complexity of the problem and the combined experiences of the driller and of water-management personnel working in programs for controlling flowing wells. 


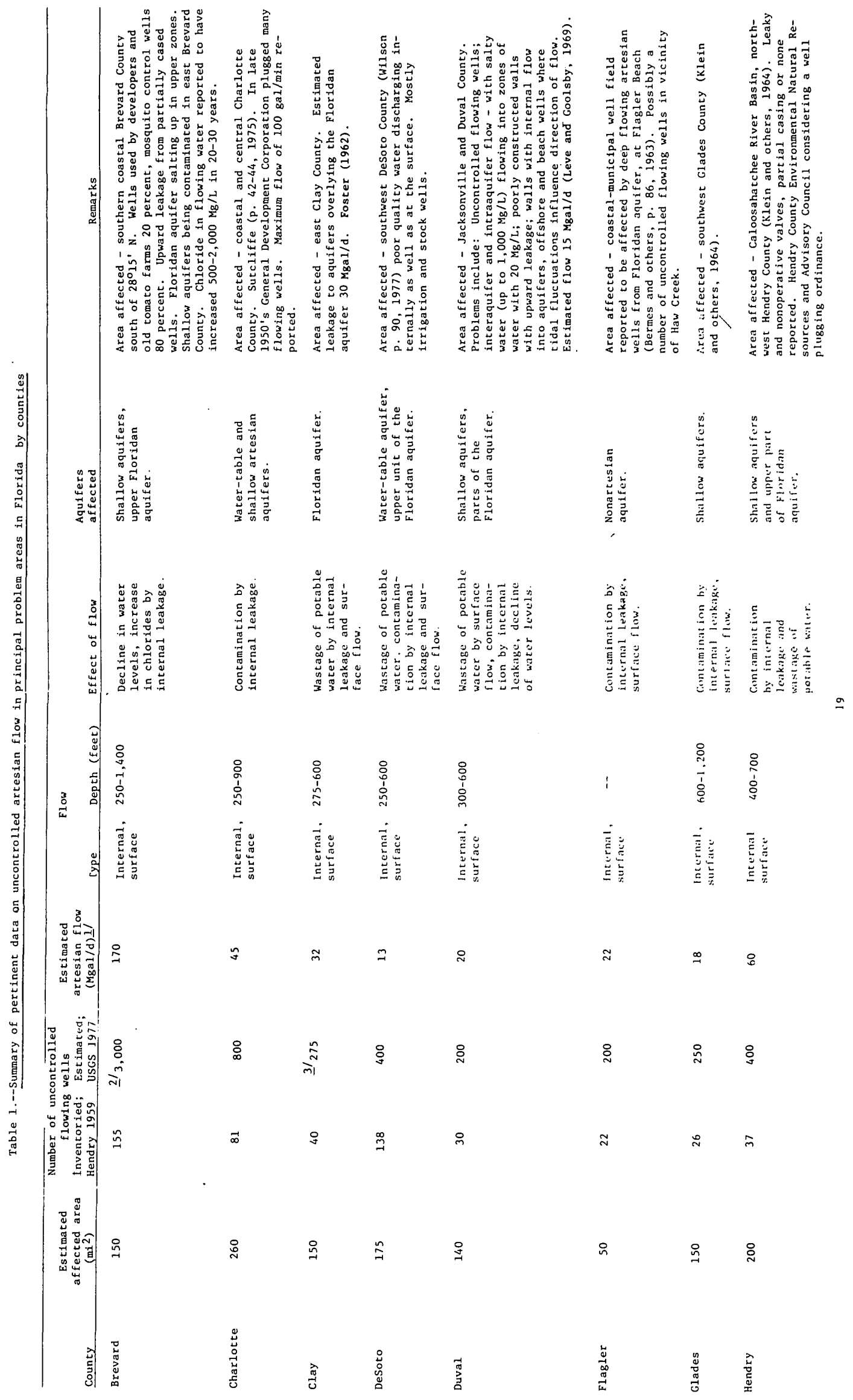




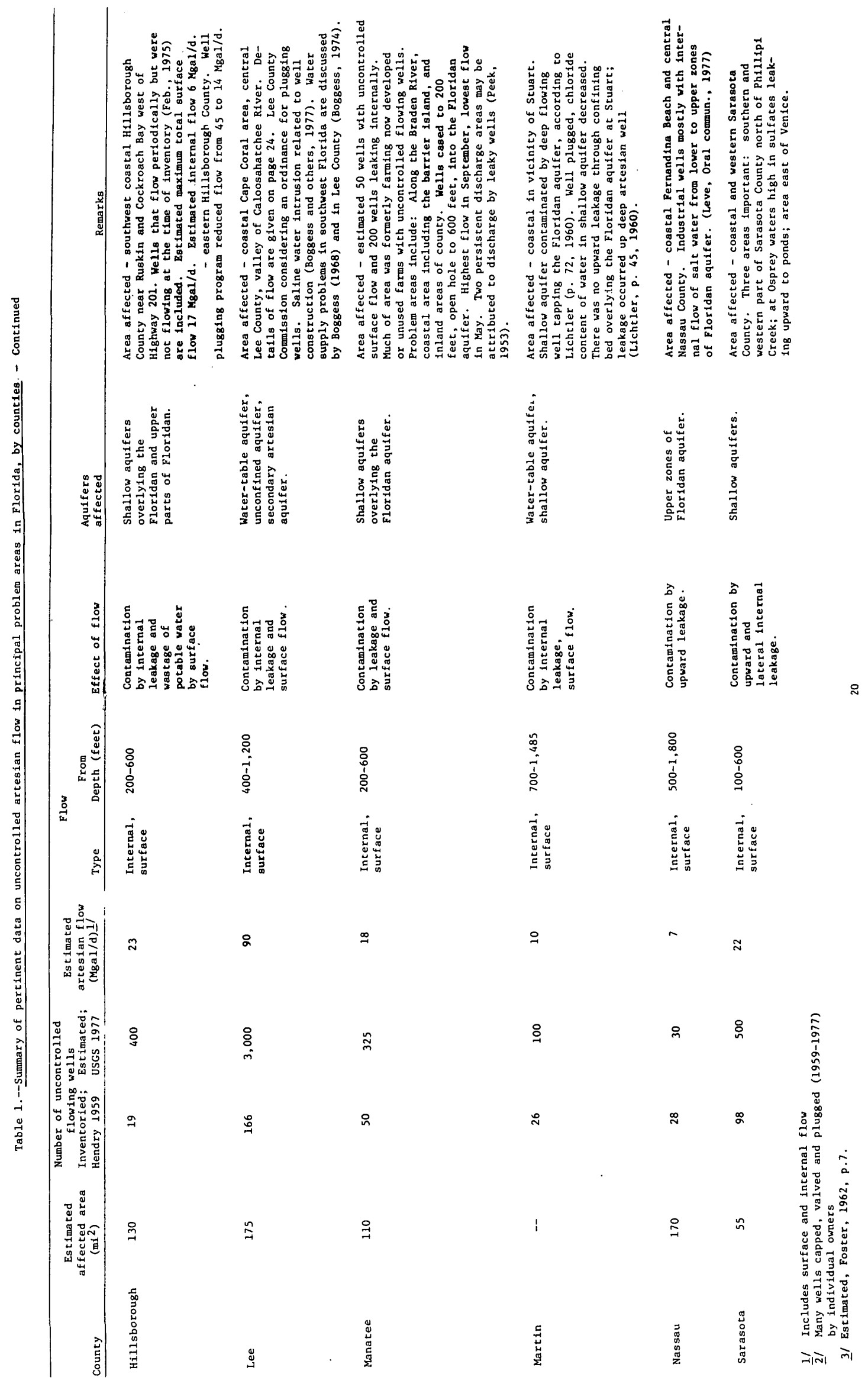


The problem of flowing wells is primarily the end result of poor well construction; that is, wells constructed without valves, with inadequate casing, with casing not properly seated or cemented, with casing that corrodes, and otherwise not drilled and constructed to conform to the local hydrologic and geologic conditions. Many of the flowing wells were constructed a number of years ago before there was full recognition of the problem that would be generated and which has been accentuated by the large increase in demand for freshwater. Further, lack of regulatory controls on well construction tended to promote promiscuous and competitive drilling which often resulted in poor well construction.

Recognition of the need for well construction commensurate with the hydrologic and geologic environment is inherent in the creation of the Water Management Districts, under the Florida Water Resources Act of 1972, Chapter 373, Florida Statutes. Under this act the Water Management Districts have the authority to permit consumptive use of water, part of which involves issuance of well permits which specify well construction in conformance with the geologic and hydrologic conditions. Also under this act, the Water Management Districts have the authority to require that flowing wells be equipped with valves to control waste or be plugged if the water is of poor quality and no longer a usable water supply.

Programs for the control of flowing wells are being carried on by federal, state, county, and municipal agencies in 21 counties and principal problem areas. The scope of individual programs in six counties are briefly summarized by counties in table 2. One well plugging program, QWIP, quality of water improvement program, in operation since 1974, is being operated by the Southwest Florida Water Management District in cooperation with their pertinent basin boards and counties.

Another program, the Agriculture Conservation Program (ACP), formerly the Rural Environmental Assistance Program (REAP) of the U.S. Department of Agriculture, Soil Conservation Service, began in 1971 in Lee County and has continued yearly except in 1973 and 1975. In addition to those counties shown on table 2, the ACP program is currently active in Brevard, Clay, Collier, De Soto, Flagler, Hendry, Indian River, Lake, Martin, Okeechobee, Putnam, St. Johns, St. Lucie, Seminole, and Volusia Counties. As of February 1978, flowing wells have been plugged in several counties as follows: Brevard, 3; Charlotte, 4; Collier, 2; Hendry, 1; Lee, 23; and St. Johns, 7 (Wyatt Thomas, oral commun., 1978).

The quality and efficacy of well construction depends primarily on the expertise and competency of the driller. As part of the statewide effort to maintain acceptable drilling standards and responsibilities of the driller, the Department of Environmental Regulation, issued about 79 new and renewed 750 driller's licenses, during July 1975-January 1978. 


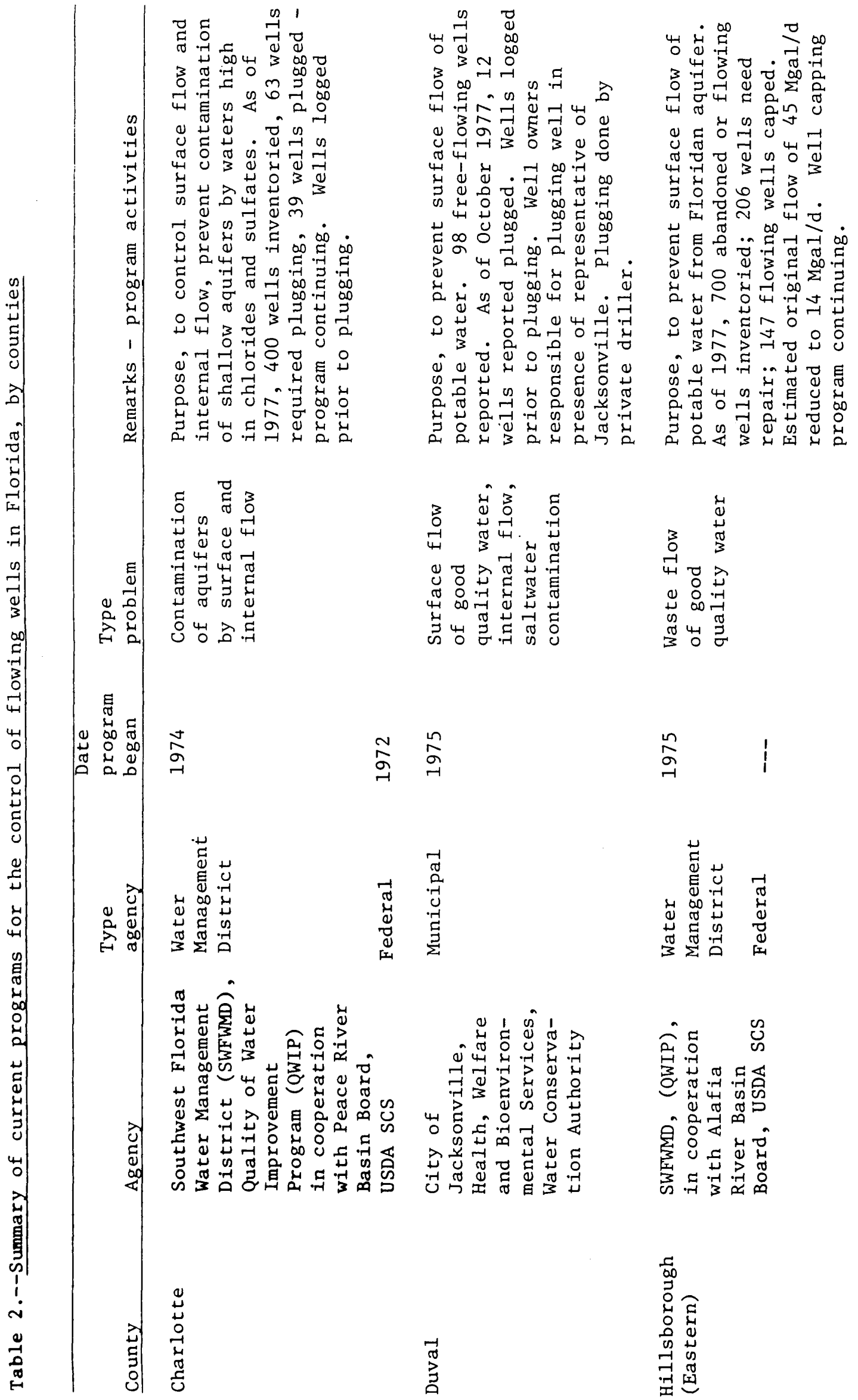




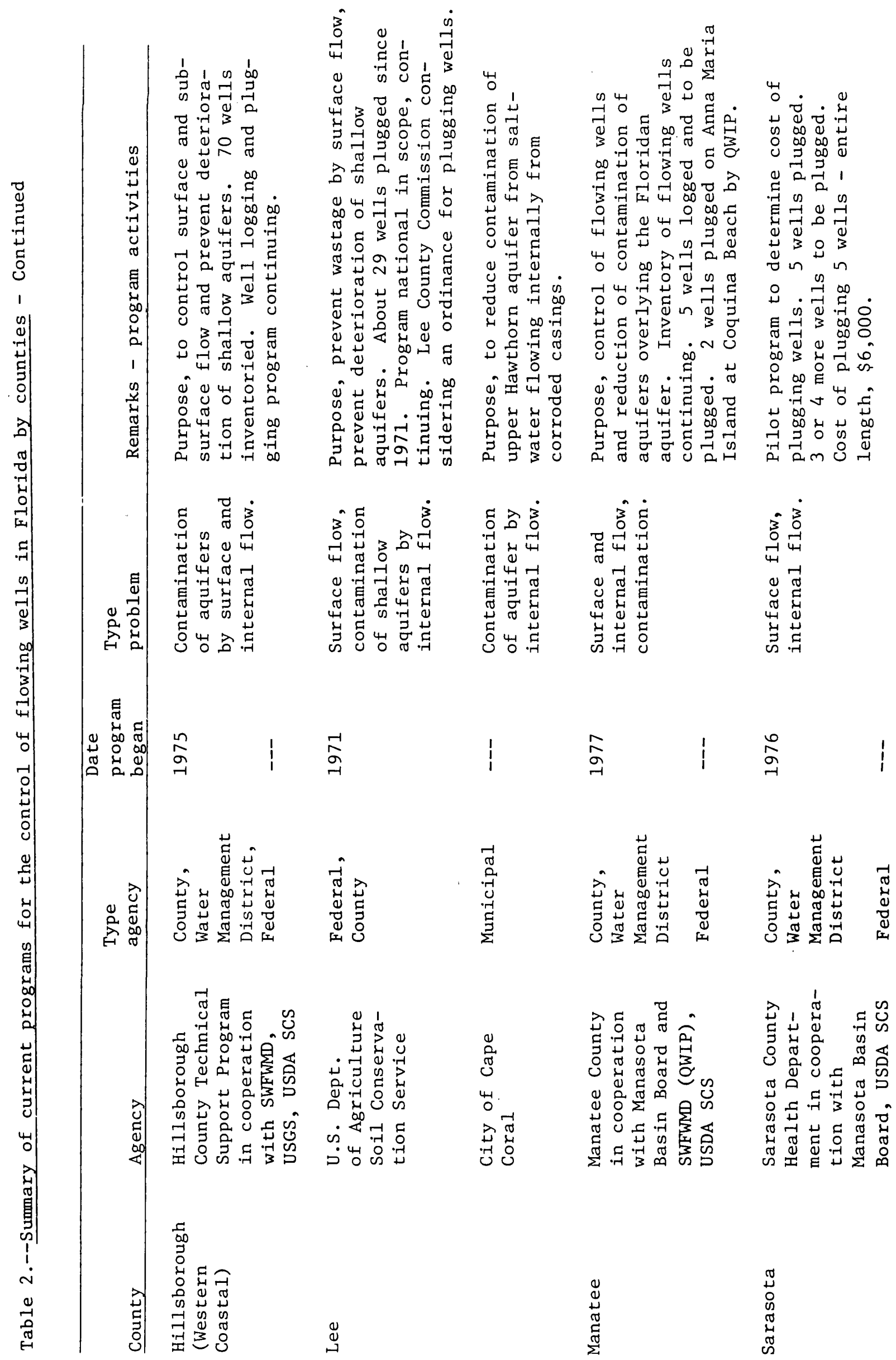


An estimated 15,000 uncontrolled flowing wells, wastefully discharge about 790 million principal of water per day by surface and internal flow. Internal flow discharges into shallow artesian and water-table aquifers through leaky casings or open well bores. Total flow in principal problem areas in 14 counties is estimated at 550 million gallons per day, or 70 percent of the statewide total.

A large percentage of the discharge from uncontrolled flowing wells is concentrated in the east-coastal and southwest coastal counties of Florida. Fourteen principal problem areas have been identified in Brevard, Charlotte, Clay, De Soto, Duval, Flagler, Glades, Hendry, Hillsborough, Lee, Manatee, Martin, Nassau, and Sarasota Counties.

Any natural or artifically induced factor that affects water resources, particularly by causing deterioration in quantity or quality of water, requires particular surveillance and careful management practices. Management is necessary to prevent deterioration of the resources. In many areas, uncontrolled discharge over the years has caused a decline in the potentiometric surface and a deterioration of the potable water aquifers. 


\section{REFERENCES}

Bermes, B. J., Leve, G. W., and Tarver, G. R., 1963, Geology and groundwater resources of Flagler, Putnam, and St. Johns Counties, Florida: Florida Geol. Survey Rept. Inv. 32, 97 p.

Boggess, D. H., 1968, Water supply problems in southwest Florida:

U.S. Geol. Survey Open-File Rept., 27 p.

1974, Saline ground-water resources of Lee County, Florida: U.S. Geo1. Survey Open-File Rept., 74-247 62 p.

Boggess, D. H., Missimer, T. M., and 0'Donnell, T. H., 1977, Salinewater intrusion related to well construction in Lee County, Florida: U.S. Geol. Survey Water-Resources Inv. 77-33, 29 p.

Causey, L. V., and Leve, G. W., 1976, Thickness of the potable-water zone in the Floridan aquifer: Florida Dept. Nat. Res., Bur. Geol. Map Series 74.

Cooper, H. H. Jr., and Stringfield, V. T., 1950, Ground water in Florida: Florida Geol. Survey Inf. Circ. 3, 7 p.

Foster, J. B., 1962, Well design as a factor contributing to loss of water from the Floridan aquifer, eastern Clay County, Florida: Florida Geol. Survey Inf. Circ. 35, $10 \mathrm{p}$.

Healy, H. G., 1972, Public water supplies of selected municipalities in Florida, 1970: Florida Dept. Nat. Res., Bur. Geol. Inf. Circ. 81,213 p.

1975, Potentiometric surface and areas of artesian flow of the Floridan aquifer in Florida, May 1974: Florida Dept. Nat. Res., Bur. Geol. Map Series 73.

1977, Public water supplies of selected municipalities in Florida, 1975: U.S. Geol. Survey Water-Resources Inv. 77-53, 309 p.

Heath, R. C., and Smith, P. C., 1958, Ground-water resources of Pinellas County, Florida: Florida Geo1. Survey Rept. Inv. 12, $139 \mathrm{p}$.

Hendry, C. W. Jr., and Lavender, J. A., 1957, Interim report on the progress of an inventory of artesian wells in Florida: Florida Geo1. Survey Inf. Circ. 10, 178 p.

1959, Final report on an inventory of flowing artesian wells in Florida: Florida Geol. Survey Inf. Circ. 21, 30 p.

Klein, H., Schroeder, M. C., and Lichtler, W. F., 1964, Geology and ground-water resources of Glades and Hendry Counties, Florida: Florida Geol. Survey Rept. Inv. 37, 101 p.

Leach, S. D., 1977, Source, use, and disposition of water in Florida, 1975: U.S. Geo1. Survey Water-Resources Inv. 78-17, 90 p.

Leve, G. W., 1966, Ground-water in Duval and Nassau Counties, Florida: Florida Geo1. Survey Rept. Inv. 43, 91 p.

Leve, G. W., and Goolsby, D. A., 1969, Production and utilization of water in the metropolitan area of Jacksonville, Florida: Florida Board of Conservation, Div. of Geol. Inf. Circ. 58, 37 p.

Lichter, W. F., 1960 Geology and ground-water resources of Martin County, Florida: Florida Geol. Survey Rept. Inv. 23, 149 p.

McCoy, H. J., 1962, Ground-water resources of Collier County, Florida: Florida Geol. Survey Rept. Inv. 31, 82 p. 
Peek, H. M., 1953, The artesian water of the Ruskin area of Hillsborough County, Florida, interim report: Florida Geol. Survey Inf. Circ. 4, $22 \mathrm{p}$.

1958, Ground-water resources of Manatee County, Florida: Florida Geol. Survey Rept. Inv. 18, $46 \mathrm{p}$. 1959, The artesian water of the Ruskin area of Hillsborough County, Florida: Florida Geol. Survey Rept. Inv. 21, 47 p.

Peek, H. M., and Anders, R. B., 1955, Interim report on ground-water resources of Manatee County, Florida: Florida Geol. Survey Inf. Circ. 6, $38 \mathrm{p}$.

Pride, R. W., 1973, Estimated water use in Florida 1970: Florida Dept. Nat. Resources, Bur. Geol. Inf. Circ. 83, 31 p.

Rosenau, J. C., and Faulkner, G. L., 1974, An index to springs of Florida: Florida Dept. Nat. Resources, Bur. Geol. Map Series 63.

Sproul, C. R., Boggess, D. H., and Woodward, H. J., 1972, Saline-water intrusion from deep artesian sources in the McGregor Isles area of Lee County, Florida: Florida Dept. Nat. Res., Bur. Geol. Inf. Circ. $75,30 \mathrm{p}$.

Sutcliffe, H. Jr., 1975, Appraisal of the water resources of Charlotte County, Florida: Florida Dept. Nat. Res. Rept. Inv. 78, 53 p.

Trapp, H. Jr., Pascale, C. A., and Foster, J. B., 1977, Water resources of Okaloosa County and adjacent areas: Water-Resources Inv. 77-9, $83 \mathrm{p}$.

Wilson, W. E., 1977, Ground-water resources of De Soto and Hàrdee Counties, Florida: Florida Dept. Nat. Res. Rept. Inv. 83, 102 p. 